\title{
PRAIRIE GRASS ESTABLISHMENT AFFECTED BY SEED TREATMENT AND SOWING DATE
}

R.E. FALLOON

Plant Diseases Division, DSIR, Palmerston North

\section{Abstract}

Effects of two different fungicide seed treatments, inoculation of seed with teliospores of the head smut fungus (Ustilago bullata Berk.), and five different autumn sowing dates, on establishment of prairie grass (Bromus willdenowii Kunth cv. 'Grasslands Matua,'), were examined in a field trial. Seedling establishment was increased by thiram seed treatment and decreased by inoculation of seed with $U$. bullata. Greater numbers of seedlings established from early sowings, when soil temperatures were higher, than from late sowings. Suitable seed treatments to increase the likelihood of successful establishment of prairie grass are discussed.

Keywords: Bromus willdenowii, seedling establishment, seed

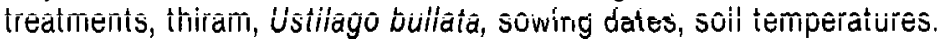

\section{INTRODUCTION}

Prairie grass cv. 'Grasslands Matua' (Bromus willdenowii Kunth) has been shown to have considerable potential as a forage grass for high fertility pastures, giving good winter and summer production under suitable grazing management (Rumball 1974; Wilson 1977; Rys et a/. 1978; Lancashire \& Brock 1983). Establishment of prairie grass has sometimes been poor, however, perhaps due to wet soil conditions, late sowing, birds feeding on seed, or poor seedling vigour (Lancashire 1978; Lancashire \& Brock 1983; J.A. Lancashire, pers. comm.). Recently Culleton \& McCarthy (1983) have shown that germination of 'Matua' seed was slow at low temperatures, and suggested that sowing prairie grass into cool soils would increase seedling susceptibility to soil-borne fungi and thus reduce seedling establishment.

Treatment of seed of ryegrasses (Lolium spp.) with protectant fungicides (e.g. captan or thiram) prior to sowing can give considerable improvement in seedling establishment (Falloon 1982). Seed of prairie grass is routinely treated with systemic fungicides to control Ustilago bullata Berk. This fungus infects young seedlings; disease symptoms eventually appear as head smut of mature plants, but infection can also adversely affect seedling establishment (Falloon 1976; 1979b). However, the fungicides most commonly used against head smut (benomyl or carboxin) have been shown to reduce seedling establishment of perennial ryegrass (Lolium perenne L., Falloon 1982), lucerne (Medicago sativa L.; R.E. Falloon \& R.A. Skipp, unpublished), and forage brassicas (Brassica spp.; R.E. Falloon, unpublished). Seedlings of these plants growing from benomyl- or carboxin-treated seed are killed by soil-borne fungi, particularly Pythium spp., in greater numbers than seedlings from untreated seed. It is possible that a similar phenomenon could occur with prairie grass, and that fungicides other than benomyl or carboxin might prove more suitable for seed treatment.

With these considerations, a field trial was carried out to measure effects of different autumn sowing dates, different fungicide seed treatments, and seed inoculation with $U$. bullata teliospores, on seedling establishment of prairie grass. 


\section{MATERIALS AND METHODS}

A seed line of $B$. willdenowii cv. 'Grasslands Matua' with high germinability (95\%; N.Z. Official Seed Testing Station) was used in this trial.

The four seed treatments used were:

untreated control;

seed inoculated with $\boldsymbol{U}$. bullata teliospores at $3.7 \mathrm{~g} / \mathrm{kg}$ seed;

benomyl (Benlate 50WP) at $5.0 \mathrm{~g} / \mathrm{kg} \mathrm{seed;}$

thiram (Thiram $80 \mathrm{WP}$ ) at $5.0 \mathrm{~g} / \mathrm{kg}$ seed.

Treatments were applied to $0.5 \mathrm{~kg}$ lots of seed in 31 capacity glass flasks; teliospores were applied dry while fungicides were applied as slurries.

Seed was sown on five occasions during autumn of 1984, into an imperfectly drained soil from Holocene siliceous sandy alluvium (Kairanga silt loam) at the DSIR flatland farm 'Aorangi', Kairanga, Manawatu. The first sowing was on 5 March and subsequent sowings were at 2 week intervals thereafter. At each sowing a randomised block experiment with four treatments replicated six times was sown. Each replicate was an $8 \mathrm{~m}$ long row, divided into four equal lengths. Replicates were $0.6 \mathrm{~m}$ apart. Counted lots of 100 seeds of each treatment were sown by hand at a depth of about $1 \mathrm{~cm}$ into rows $2 \mathrm{~m}$ long. This is equivalent to a sowing rate of approximately $9 \mathrm{~kg}$ seed/ha. The five sowings were carried out adjacent to each other in a plot measuring $15 \times 12 \mathrm{~m}$. At 2, 4 and 6 weeks after each sowing, numbers of seedlings in rows were counted.

Soil temperatures were measured at $4 \mathrm{~h}$ intervals throughout the trial, at $0200 \mathrm{~h}$ to $2200 \mathrm{~h}$ each day. Temperatures were measured at a depth of $3 \mathrm{~cm}$, using three thermistor probes (Grant Instruments, CM-U) placed about $3 \mathrm{~m}$ apart and immediately adjacent to the trial plot. Screened air temperature was recorded at the same times at $10 \mathrm{~cm}$ above soil level with a single thermistor probe. The probes were connected to a multi-channel temperature recorder (Grant Instruments). Rainfall records for the trial period were obtained from a meteorological station (N.Z. Meteorological Service, Kairanga) approximately $400 \mathrm{~m}$ from the trial site.

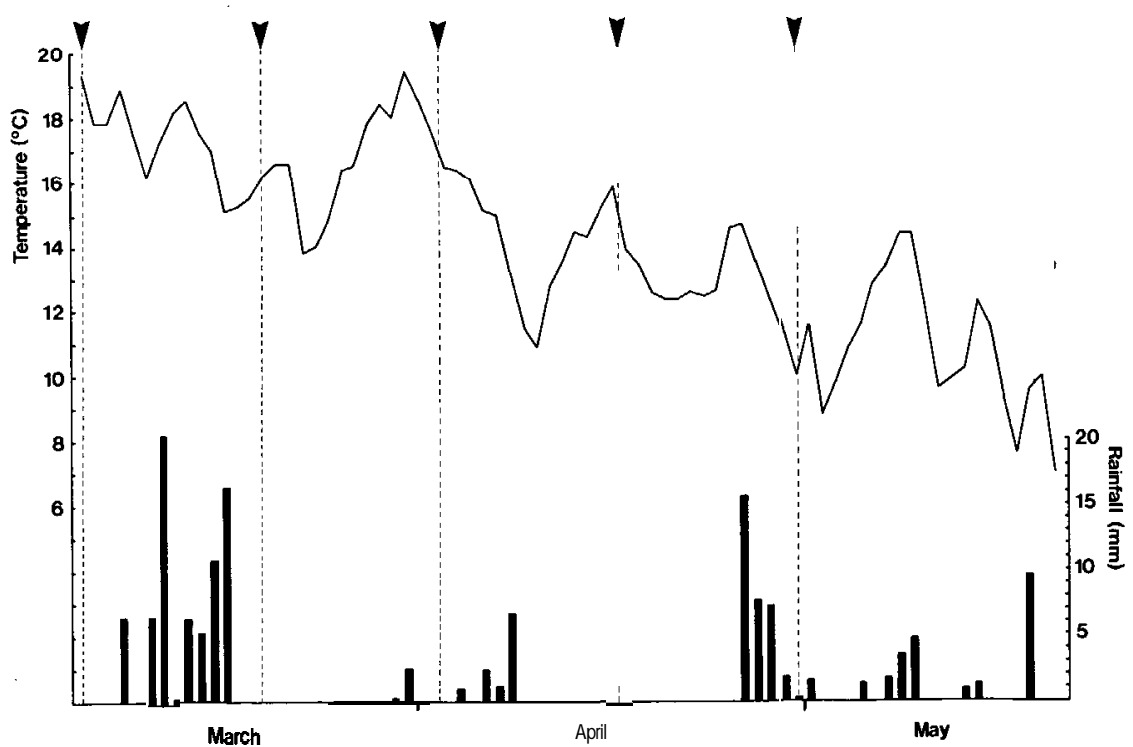

Figure 1: Mean daily 3.cm depth soil temperatures and daily rainfall records for the period 5 March to 20 May, 1984. Trial sowing dates are indicated with arrows. 


\section{RESULTS}

\section{Soil temperatures}

Daily mean soil temperatures for the period of the trial are shown in Fig. 1. Although daily means varied considerably, there was an overall downward trend in soil temperatures for the 3 month period, from about $18^{\circ} \mathrm{C}$ at the time of the first sowing to about $10^{\circ} \mathrm{C}$ at the fifth sowing.

Diurnal temperature fluctuations were marked, particularly during the period in which the first three trial sowings were carried out. Diurnal variations of $14^{\circ} \mathrm{C}$ were commonly measured during this period. Later, after the fifth sowing, variations were often only 4 to $6^{\circ} \mathrm{C}$.

Rainfall

Over the 2 weeks following the first sowing, rain in excess of $5 \mathrm{~mm}$ was recorded on 7 days (Fig. 1). From then until just before the fifth sowing only small amounts of rainfall were recorded, and the soil was very dry at the time of the third and fourth sowings. Seed was sown into moist soil at the fifth sowing.

\section{Seedling establishment}

Data of seedling establishment from different sowings and different seed treatments are summarised in Fig. 2. Statistical analysis of arcsine square root transformed data indicated that differences between means both for sowing dates and seed treatments were significant $(P<0.001)$, as was the sowing dates $X$ seed treatments interaction.

The proportions of seedlings established from untreated seed 6 weeks after each of the first three sowings were 54 to $58 \%$ of the number of viable seeds sown. Numbers of seedlings from the fourth and fifth sowings were 42 and $45 \%$ respectively, less than from the first sowing $(P<0.05)$. Rates of seedling emergence decreased with successive sowings. Maximum numbers of seedlings from untreated seed at the first sowing were recorded by 2 weeks, whereas from the last three sowings, maximum numbers were recorded at 4 or 6 weeks after sowing.

The different seed treatments affected seedling establishment each in a different manner. Seed inoculated with $U$. bullata teliospores prior to sowing gave fewer seedlings than controls from all sowings except the last $(P<0.05)$. The greatest decreases in numbers of seedlings from this treatment were after the second and third sowings, when establishment was about half that of the controls. The $U$. bullata inoculation treatment was the only one for which numbers of seedlings decreased markedly between 2 and 6 weeks after sowing; this effect occurred after each of the first three sowings. Dead or wilted seedlings with severely decayed roots were noted in rows sown with this treatment. A variety of fungal species was isolated in the laboratory from roots of dead seedlings. These included Fusarium oxysporum Schlecht.:Fr (43\% of 30 isolates obtained), Chaetomium globosum Kunze:Fr. (27\%), and single isolates of Ceratobasidium cornigerum (Bourdot) D.P. Rogers, F. culmorum (W.G. Smith) Sacc., Phialophora radicicola Cain, and a Phomopsis sp.

Seed treatment with benomyl gave small increases in numbers of seedlings compared with controls from each sowing, but this effect was statistically significant only from the third sowing $(P<0.05)$. Numbers of seedlings established from benomyl-treated seed decreased with successive sowings as was observed for untreated seed.

Numbers of seedlings from thiram-treated seed varied from 68 to $79 \%$ of viable seeds sown, and were significantly greater than controls from all sowings $(P<0.05)$. Increases in numbers of seedlings from this treatment over untreated seed were $26 \%, 34 \%, 47 \%, 63 \%$ and $65 \%$ from the first to fifth sowings respectively. 


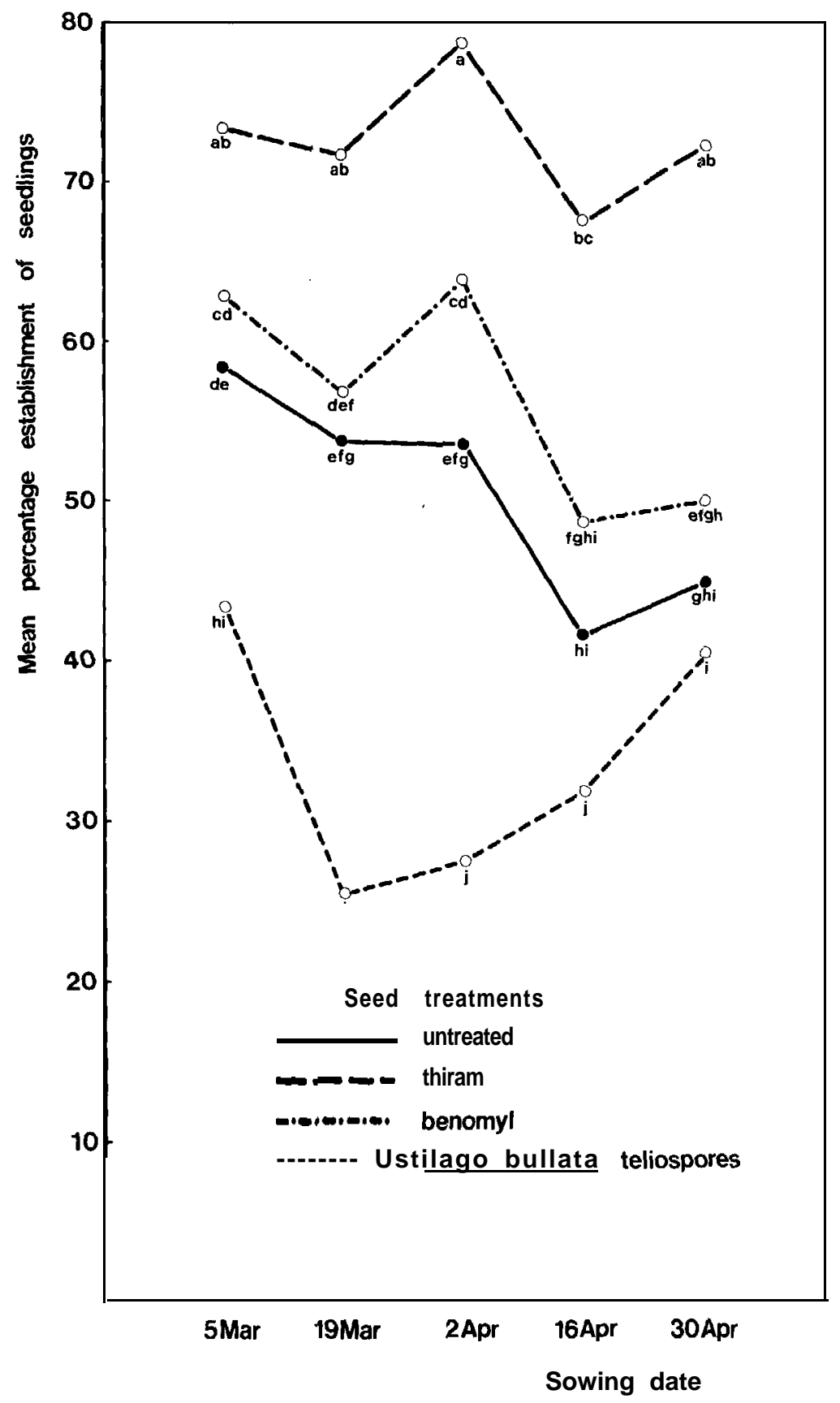

Figure 2: Establishment of prairie grass seedlings (percentage of viable seeds sown) 6 weeks after sowing on each of five dates. Means accompanied by the same letter are not significantly different $(P<0.05)$ for arcsine square root transformed data. 


\section{DISCUSSION}

This field trial has demonstrated effects of several factors upon seedling establishment of prairie grass. Increased establishment over untreated seed occurred from seed treated with thiram. Decreased establishment was recorded from $U$. bullata inoculated seed and from late sowings. Although seedling establishment from seed treated with benomyl was not greater than from seed treated with thiram, there was no adverse effect of benomyl treatment on prairie grass establishment compared with untreated seed.

Protectant fungicides, such as thiram, improve seedling emergence by controlling soil-borne pathogenic fungi. These fungi kill grass seedlings soon after germination commences (Falloon 1985). Proportional increases in establishment from thiram-treated seed were greatest after the late sowings, when soils were cool and diurnal temperature fluctuations less marked, than after early sowings. These results reinforce the suggestion of Culleton \& McCarthy (1983) that prairie grass seedlings may better withstand pathogens when germinating in warm conditions.

Soil temperatures may also have affected the activity of $U$. bullata in this trial. Seedling death from teliospore-inoculated seed was greatest from early sowings, while establishment for both inoculated and untreated seed was similar from the last sowing. Previous studies (Falloon 1979a) have shown that reductions in seedling survival due to seed inoculation with U. bullata were greatest at 20 to $25^{\circ} \mathrm{C}$, but did not occur at $10^{\circ} \mathrm{C}$.

Teliuspore inoculation of seed may have increased susceptibility of resulting seedlings to attack by root-invading fungi (Fischer \& Holton 1957). Dry soil conditions at the time of the third and fourth sowings may have exacerbated the effects of these fungi. However, the organisms isolated from roots of dead seedlings growing from teliospore-inoculated seed were all species considered to be weak pathogens or secondary invaders of grass roots (R.A. Skipp \& M.J. Christensen, pers. comm.).

This field trial has shown the benefit of fungicide seed treatment of 'Matua' prairie grass prior to sowing. Seed treatment is necessary to ensure good seedling establishment by reducing effects of soil-borne fungal pathogens. Furthermore, control of seed-borne $U$. bullata is essential. This fungus can reduce seedling establishment, and infected plants produce less herbage than healthy plants (Falloon 1976; 1979b) and give low seed yields (Luttrell \& Craigmiles 1961). Thiram, beside giving increased seedling establishment, also controls $U$. bullata seedling infection, but only at very high rates (12 g/kg; Falloon 1980). The systemic fungicides benomyl and carboxin control U. bullata seedling infection at lower rates than thiram (Falloon 1980), while systemic fungicides that inhibit sterol biosynthesis in fungi (e.g. nuarimol, propiconazol, or triadimenol) are even more active against this fungus (R.E. Falloon \& M.P. Rolston, unpublished). The most appropriate seed treatment for prairie grass would therefore be a combination of fungicides including a protectant with one of these systemic compounds. Adequate seed treatment coupled with sowing into warm soils in early autumn should increase the likelihood of successful establishment of prairie grass pastures and seed crops.

\section{ACKNOWLEDGEMENTS}

Technical assistance was given by Miss S. Bell, Miss C. Grammer and Mrs K. Neale. Mr R.H. Fletcher advised on matters statistical, and helpful discussions with Mr J.A. Lancashire were appreciated.

\section{REFERENCES}

Culleton, N.; McCarthy, V. 1983. Ir. J. agric. Res. 22: 31-36.

Falloon, R.E. 1976. N.Z. J. agric. Res. 19: 249-254. 
1979a. Trans. Brit. Mycol. Soc. 73: 41-47.

1979b. N.Z. J. agric. Res. 22: 621-626.

1980. N.Z. J. exp. Agric. 8: 173-177.

1982. Proc. N.Z. Grass/d Ass. 43: 139-143.

1985. Plant and Soil (in press).

Fischer, G.W.; Holton, C.S. 1957. Biology and Control of the Smut Fungi. The Ronald

Press. New York. $x+622$ pp.

Lancashire, J.A. 1978. Proc. Agron. Soc. N.Z. 8: 123-127.

; Brock, J.L. 1963. Proc. N.Z. Grassid Ass. 44: 61-73.

Luttrell, E.S.; Craigmiles, J.P. 1961. Plant Dis. Reptr 45: 216-218.

Rumball, W. 1974. N.Z. J. exp. Agric. 2: 1.5.

Rys, G.J.; Ritchie, I.M.; Smith, R.G.; Thomson, N.A.; Crouchley, G.; Stiefel, W. 1978. Proc. N.Z. Grassld Ass. 39: 148-155.

Wilson, G.F. 1977. N.Z. agric. Sc. 11: 47-48. 